УДК 304.444:659.148(477)

\author{
Світлана Валеріївна Заря, \\ кандидат мистецтвознавства, \\ завідувач кафедри естрадного співу, \\ Київська муніципальна академія \\ естрадного та циркового мистецтв, \\ Київ, Україна \\ ORCID: 0000-0001-8047-7068
}

\title{
АУДІОВІЗУАЛЬНІ РЕКЛАМНІ ТВОРИ 3 НАЦІОНАЛЬНОЮ ТЕМАТИКОЮ ЯК КУЛЬТУРНИЙ ФЕНОМЕН СУЧАСНОЇ УКРАЇНИ
}

Анотація. У статті досліджуються особливості сучасного творчого виробництва таких телевізійних проектів, як аудіовізуальні рекламні твори, що характеризуються використанням українських національних мотивів i позиціонуються рекламними кампаніями як культурний феномен сучасної України. Метою дослідження є простежити сучасну тенденцію використання патріотичного історичного образу, національних традицій і минулого українського народу в україномовній рекламі як ефективного засобу масової комунікації у вітчизняному відеовиробництві, виявити специфіку української національно-культурної складової у рекламі та виділити характерні риси відеоряду аудіовізуальних рекламних творів, де лейтмотивом сюжету $\epsilon$ український національний колорит. Сучасні українські торгові марки звертаються до теми національних традицій у культурі та мистецтві, використовуючи їх в аудіовізуальних творах.

Кожна країна має свій рекламний стиль, що зумовлено особливостями національної свідомості, історією національних традицій. Менталітет нації та умови, у яких вона побутує, - це основна ознака рекламних повідомлень тієї країни, в якій вони 
транслюються. Географічна особливість сприйняття та технічні можливості накладають свій стиль на будь-яку рекламну кампанію. Рекламні відеоролики, у яких відображено народні традиції й асоціативні історичні образи, є потужним чинником формування позитивного іміджу як українського виробника, так i українського суспільства у світі. Телевізійна реклама, безумовно, є потужним суспільним і культурним механізмом впливу на масову аудиторію. Як культурологічний феномен вона відіграє важливу роль для збереження національної культури та традицій, закріплення та відродження національної самосвідомості суспільства як в окремих своїх проявах, так і в цілісному розумінні цього питання. Ця розвідка базується на ретельному системному аналізі численних прикладів національної рекламної відеопродукції з погляду ефективності їі впливу на вітчизняну аудиторію.

Ключові слова: реклама, рекламний відеоролик, аудіовізуальний рекламний твір, національна культура, національні традиції, патріотизм.

Вступ. На сьогодні реклама загалом і рекламні ролики зокрема $\epsilon$ невід'ємною частиною сучасного українського суспільства. Історія виникнення реклами почалась давно та пройшла вже певний період становлення. За цей час дуже багато змінилося, але реклама стає актуальнішою 3 кожним днем все більше. Реклама - це сучасна й цікава, до кінця не досліджена форма мистецької діяльності.

Постановка проблеми. У статті проаналізовано рекламні ролики 3 національною тематикою як культурний феномен сучасної України.

Аналіз останніх досліджень і публікацій. За довгий період часу рекламу розглядали багато вітчизняних і зарубіжних науковців. Серед них: В. В. Ученова, О. В. Катернюк, Є. А. Сліна, В. Л. Музикант, Ф.Г. Панкратов, І. В. Крилов, 
Л. М. Хромов, А. В. Ульяновський, Дж. Бернет, У. Бове К. Аренс, У. Уеллс, Ч. Морріс, Д. Огілві, К. Хопкінс та ін.

Як стверджувала дослідниця Є. А. Єліна, «Сьогодні реклама як об'єкт вивчення володіє потужною привабливою силою» [5]. «Реклама (від лат. reclamare - вигукувати) - це форма комунікації, що має на меті перекласти якість товару $\mathrm{i}$ послуг на мову потреб споживача», а також - інформаційне повідомлення [2, с.117].

Практичний аспект телевізійної реклами розглядали В. Аренс, Р. Барт, К. Бове, І. А. Гольман, А. Дейян, Д. Залтман, Г. Картер, Ф. Котлер, С. Моріарті, Д. Огілві, Ф. Г. Панкратов, Ч. Сендідж, Д. Траут, В. Фрайбургер, Л. М. Хромов та ін.

Як стверджував Л. М. Хромов, «реклама сприяе орієнтації виробництва на задоволення потреб людей» [11].

У статті послуговуємося таким смисловим наповненням рекламного відеоролика, як звукового фільму, головним завданням якого $\epsilon$ за декілька секунд привернути увагу глядача та вразити своєю цікавістю та необхідністю.

«Рекламні телевізійні ролики являють собою міні-твори “комерційного мистецтва", де за 20-30 секунд ефірного часу розігруються сценки-вистави», - пише С. Герасимова $[4$, c. 118].

Мета статті - простежити сучасне прагнення рекламних кампаній у використанні в рекламних роликах мотивів українських національних традицій.

Виклад основного матеріалу. Як стверджує відома дослідниця реклами Н. А. Анашкіна: «Реклама $є$ відображення нашого життя. А завдання творчості в реалістичному мистецтві - розкриття сутності зображуваних явищ життя» $[1$, с. 26].

Кожна країна має свій рекламний стиль, що зумовлено особливостями національної свідомості, історією національних традицій. Менталітет нації та умови, у яких вона побутує, - це основна ознака рекламних повідомлень тієї країни, в якій вони транслюються. Географічна особливість сприйняття та технічні 
можливості накладають свій стиль на будь-яку рекламну кампанію.

Наприклад, в американській рекламі все чітко, раціонально та за всіма законами рекламної науки, а головне вона спрямована на підтримку власного виробника, сприяє формуванню почуття патріотизму та «американської мрії» [4, с. 119]. Французька реклама відрізняється витонченим смаком, вона дуже смілива, розумна та вишукана, як і самі французи. У німецьких рекламних повідомленнях емоції зведені до мінімуму, перевагу надано достовірності. У Таїланді, на відміну від інших країн, знімають прості та смішні рекламні ролики тому вони дуже цікаві, неповторні i, навіть можна сказати, божевільно креативні [2]. Щодо України, то А. Федоров (Креативне бюро «Sahar») констатував, що «в Україні набагато менше, порівняно з іншими країнами, прямої, агресивної реклами, яка звертається безпосередньо до людини і вказує, що вона повинна робити» [9, с. 36].

Дослідники розрізняють два основні види реклами: соціальну та комерційну. Науковець Ю. С. Бернадська пише: «Якщо комерційна реклама прагне насамперед спонукати споживача зробити покупку, то мета соціальної реклами змінити ставлення громадськості до якої-небудь нагальної соціальної проблеми, а в довгостроковому періоді - створити нові соціальні цінності» [3, с. 15].

Як соціальна, так і комерційна реклама ставить завданням - запам'ятатися та вплинути на глядача, оскільки «реклама - це саме психологічне програмування людей» [6, c. 42].

В Україні головним завданням соціальної реклами $\epsilon$ привернути увагу людей до суспільних проблем країни та моральних цінностей. Наприклад: «Ні палінню», «Ні насиллю в сім’ї»; «За всиновлення дітей» та ін. Завдяки подіям, які відбуваються 3 к. 2013 р., рекламні заклики, особливо соціального плану, змінили свою тематику: «Ні війні!», 
«Україна перш за все!» тощо. До цього циклу рекламних роликів належать твори, які з'явилися на телебаченні наприкінці липня 2014 р., 3 головним слоганом «Повертайтесь живими», а також патріотичний ролик «Захистимо Україну». Такі яскраві ролики налаштовують на віру і надію на перемогу.

У сучасному українському суспільстві нині триває бурхливий процес повернення до національних культурних цінностей і традицій, відродження національної самосвідомості та гідності. Якщо раніше ми бачили на телевізійних каналах більшість рекламних роликів комерційного характеру та розважального типу, то зараз більшість рекламних звернень $\epsilon$ соціальними, де пропагуються любов та повага до своєї землі й національної історії, формується українська свідомість.

Ще кілька років тому навіть ніхто не думав, що так зміниться життя і таким необхідним буде використання мотивів національних традицій, навіть у рекламних роликах.

Наприклад, «Укртелеком» створив, на наш погляд, рекламу, яка зараз просто необхідна для кожного 3 нас. Це реклама 3 головним слоганом «Єднаймось ми - єднається країна». Ідея ролика в підтримці іншої людини, у тому, що все відбувається на краще й усілякі проблеми перетворюються на посмішку. Коли ми підтримуємо один одного, ми єднаємось, а коли ми єднаємось - єднається вся країна. Музичний супровід створив В. Крипак.

Як уже зазначалося, звернення рекламного повідомлення на телебаченні дуже обмежене за часом - 20-30 секунд. За цей час багато чого потрібно донести глядачеві, зачепити струну його серця та налаштувати на краще: «Все буде добре», як у пісні популярного українського співака С. Вакарчука. Цікаво нагадати, що ця пісня була темою й комерційного рекламного ролика цукерок «ROSHEN», а сам лідер рок-гурту «Океан Ельзи» С. Вакарчук також знімався в рекламі мобільного оператора «МТС». Однак ідея ролика «МТС» вийшла за межі 
комерційного контексту (нульовий тариф дзвінків у 22 країни), перетворившись у розповідь усьому світу про Україну.

Отже, відбулись певні зміни суспільної свідомості та переоцінка цінностей культурної сфери, тому змінилася й комерційна реклама - вона теж часом набула патріотичного характеру. Україна - сильна та дуже гарна країна, зі своєю історією, національними традиціями, зі стилем життя. Джерелом української культури завжди була народна творчість, яка передавалась із покоління в покоління.

Ще один 3 прикладів - рекламний ролик води «Моршинська», в якому знімалася популярна українська співачка Руслана, що стала одним із символів українського патріотизму. У рекламному ролику «Моршинська» Руслана показана в аутентичному асоціативному образі. Яскрава етнічна ідентифікація у професійній подачі одночасно поєднується зверненнями до етнічних коренів і справжньої танцювальної свободи. Дивовижне сплетіння містичних ритуалів i традиційних мотивів, які зберігалися та передавалися на Гуцульщині ще 3 дохристиянських часів. Автори створили музичне й стилістичне бачення водної стихії, яку підкреслили культові етнічні барабани та сучасні танцювальні біти, чаруючий поклик трембіт і неймовірна гра труб у гуцульській манері.

Ще одним із прикладів $\epsilon$ реклама компанія «Наш молочник», що 2014 р. відзняла ролик про те, як робиться справжнє домашнє українське масло. Було використано ідею, що 3 давніх часів масло робили в кожній українській сім'ї, збиваючи вершки: на початку ролика з'являється гарна жінка у вишиванці, яка збиває масло в старовинній ступі, а до неї біжать онуки, вдягнуті також в українські костюми, дітей жінка пригощає смачним хлібом з маслом. Цей відеоряд супроводжує музика етнічного українського характеру, яку написав український композитор багатьох рекламних роликів Є. Бедненко. 
Тема відтворення національного колориту в рекламі (зокрема у відеорекламі) наразі $\epsilon$ доволі актуальною, проте грунтовної розробки даної проблематики на науковому рівні досі бракує.

2008 р. торгова марка «Gala» для того, щоб підтримати українського виробника, випустила напередодні святкування свята Великодня свою продукцію, на якій було зображення петриківського розпису. У Петриківці й досі зберігають традиції народного розпису, які розвиваються вже сучасними художниками.

Сучасні українські торгові марки звертаються до теми національних традицій у культурі та мистецтві, використовуючи їх в аудіовізуальних творах - відеороліках. Рекламні кампанії для зацікавленості споживачів почали демонструвати старовинні традиції святкування народних свят.

Наприклад, торгова марка «Львівське» випустила низку рекламних роликів, присвячених таким святам, як Трійця, Спас, Великдень, Новий рік.

У відеоролику про ніч на Івана Купала показано, як саме проходить свято: тут і плетіння вінків і пускання їх на воду молодими дівчатами; і стрибання через багаття та пускання 3 гори палаючого колеса як символу літнього сонцевороту. У рекламі спеціально знімали молодь для наголошення на тому, що традиції не вмирають, а стають ще дорожчими та передаються через покоління.

Торгова марка «Горілочка» випустила яскраві українські рекламні ролики продукції «Купала», де теж використала особливості свята (стрибання через вогонь, ворожіння про заповітне, кружляння в хороводі), і «Покрова», у якому знято в образах козаків сильних, із гарними фігурами, чоловіків, i виголошується заклик «Сднаємося духом!». Дійства супроводжує музика етнічного характеру. Основну мету цих рекламних проектів окреслив маркетинговий директор кампаній 
А. Боюнець: «Наш продукт - це частина глибоко національної традиції народного гуляння» [7].

Окремо підкреслимо, що автори реклами звертаються не тільки до вікової історії, а й до символу незламної України народної пісні. Вона ллється ніби 3 глибини душі багатостраждального українського народу. Так багато що випробував та болісно довго страждав народ, тому не може не співати душевні пісні. Усі без винятку народні пісні прожиті та народжені на безкрайніх i неосяжних просторах української землі, чіпляють найтонші струни нашої душі та змушують битися серце сильніше, пробуджуючи в нас неймовірну любов до історії народу та краси й колориту народних традицій України.

Так, до Дня Незалежності було створено рекламний ролик від компанії «BBDO Ukraine» для марки «Чернігівське». Ця компанія випустила серію під назвою «Українська пісня»: на кожній із чотирьох банок наведено слова українських пісень. Творча ідея та сюжет ролика: людина, яка їде в метро або йде по вулиці, чує з навушників українську пісню та починає іiі співати вголос, а люди, які знаходяться поруч, підхоплюють іiі i співають усі разом. Як стверджувала менеджер 3 маркетингу бренду А. Руденко: «Ми хотіли цим відео не тільки нагадати українцям наші традиції, а й заохотити їх слухати та співати українські пісні» [8].

У ролику «Львівське живе» також звучить прекрасна народна пісня «Ой Верше, мій Верше» в дуже ніжному та чуттєвому виконанні молодої української сучасної співачки, поетеси та композитора ILLARIA.

У листопаді 2011 р. в ефірі всіх національних каналів з'явився ролик для торгової марки «Чернігівське». Його героєм став хлопець, справжній українець, хоробрий, патріот своєї країни. У душі кожного українця завжди $є$ бажання бути переможцем, першим, бути готовим до здолання різних перешкод і труднощів. Як герой ролика хоче бути першим, так i 
рекламна кампанія, яка представляє свій національний продукт, теж знаходиться на перших місцях у рейтингах з продажу свого товару.

Ще один 3 яскраво виражених патріотичних роликів, який не можна не згадати, - це ролик «Україна. Загартована болем». У головній ролі знімається М. Гаврилюк - хлопець, над яким знущались під час «Революції гідності», роздягнувши його на морозі, а він стверджував: «Я козак і дав клятву захищати людей».

Проект не комерційний, а волонтерський. Ідея ролика в тому, що на тілі М. Гаврилюка голкою вишивається вишиванка. I тому настрій твору дуже напружений, а музичний супровід налаштовує людину на роздуми. Символіка української вишиванки дуже актуальна нині.

Отже, тема відтворення у відеорекламі історичного культурного образу, заснованого на національному колориті, наразі є доволі актуальною, проте грунтовної розробки даної проблематики на науковому рівні не вистачає. Це стосується не лише чіткого теоретичного визначення культурологічного значення відеореклами, а й дослідження художньої стилістичної специфіки рекламних роликів, що відображають запит суспільства на автентичність джерел та історичність пропонованих образів як невід'ємну частину загальної складової національного-культурного продукту.

$\mathrm{He}$ менш важливим $є$ й той факт, що рекламні відеоролики, в яких відображено народні традиції та асоціативні історичні образи, $\epsilon$ потужним чинником формування позитивного іміджу як українського виробника, так i українського суспільства у світі. Особливості сприйняття, поведінки та мислення відіграють важливу роль у правильному плануванні та проведенні рекламних кампаній, формуванні яскравого національно-стильового визначення продукту як на внутрішніх, так і зовнішніх ринках. До того ж, національноетнічні особливості сприйняття суспільної поведінки та 
мислення відіграють важливу роль у формуванні національної свідомості та розуміння глядацької аудиторії.

Висновки. Підсумовуючи сказане вище, можна зробити висновок, що телевізійна реклама, безумовно, $\epsilon$ потужним суспільним i культурним механізмом впливу на масову аудиторію. Як культурологічний феномен вона відіграє важливу роль для збереження національної культури та традицій, закріплення та відродження національної самосвідомості суспільства як в окремих проявах, так і в цілісному розумінні цього питання. В роботі доведено, що в Україні реклама набула нового статусу. Можна стверджувати, що вона одночасно соціальна й комерційна, іміджева й асоціативна, національна та патріотична, така, що реалізує актуальний, досить гострий запит суспільства на повернення до історичних образів і героїв української історії.

\section{Література}

1. Анашкина Н. Режиссура телевизионной рекламы. Москва: Юнити-Дана, 2008. 26 с.

2. Бабынина $K$. Кафедра маркетинга и рекламы. Реклама и массовая культура к проблеме определения бренда. URL: http://kafmr.rggu.ru/index.php?id=622

3. Бернадская Ю., Марочкина С., Смотрова Л. Основы рекламы. Москва: Наука, 2005. 281 с.

4. Герасимова $C$. Культурология и теория телекомуникации: элементарный курс: учебное пособие. Москва: Гардарики, 2007. $173 \mathrm{c}$.

5. Елина E. Семиотика рекламы. URL: http://bookonline.com.ua/read.php?book=3754

6. Мокшанцев Р. Психология рекламы: учебное пособие. Москва: ИНФРА-М, 2000. 42 с.

7. Народ жив, пока живы его традиции. URL: http://www.adme.ua/creativity/narod-zhiv-poka-zhivy-egotradicii-128162/ 
8. Украинская песня в каждом из нас. URL: $\quad$ http://www.adme.ua/creativity/ukrainskaya-pesnya-vkazhdom-iz-nas-bbdo-kyiv-128492/

9. Федоров А. Украина - не Россия. Рекламные идеи. 2009. №2. Cc.36-38.

10. Феофанов О. Реклама. Новые технологии в России.

Санкт-Петербург: Питер, 2000. 384 с.

11. Хромов Л. Рекламная деятельность.

URL: http://udik.com.ua/books/book-815/chapter-29236/

\section{Светлана Валерьевна Заря,}

кандидат искусствоведения, заведующая кафедрой эстрадного пения,

Киевская муниципальная академия

эстрадного и циркового искусств,

Киев, Украина

ORCID: 0000-0001-8047-7068

\section{АУДИОВИЗУАЛЬНЫЕ РЕКЛАМНЫЕ ПРОИЗВЕДЕНИЯ С НАЦИОНАЛЬНОЙ ТЕМАТИКОЙ КАК КУЛЬТУРНЫЙ ФЕНОМЕН СОВРЕМЕННОЙ УКРАИНЫ}

В статье исследуются особенности современного творческого производства таких телевизионных проектов, как аудиовизуальные рекламные произведения, характеризующихся использованием украинских национальных мотивов, которые позиционируются рекламными кампаниями как культурный феномен современной Украины. Целью исследования является проследить современную тенденцию использования патриотического исторического образа, национальных традиций и прошлого украинского народа в украиноязычной рекламе как эффективного средства массовой коммуникации в отечественном видеопроизводстве, выявить специфику 
украинской национально-культурной составляющей в рекламе и выделить характерные черты видеоряда аудиовизуальных рекламных произведений, где лейтмотивом сюжета является украинский национальный колорит. Современные украинские торговые марки обращаются к теме национальных традиций в культуре и искусстве, используя их в аудиовизуальных произведениях.

Каждая страна имеет свой рекламный стиль, обусловленный особенностями национального сознания, историей национальных традиций. Менталитет нации и условия, в которых она бытует, - это основной признак рекламных сообщений той страны, в которой они транслируются. Географическая особенность восприятия и технические возможности накладывают свой стиль на любую рекламную кампанию. Рекламные видеоролики, в которых отражены народные традиции и ассоциативные исторические образы, является мощным фактором формирования положительного имиджа, как украинского производителя, так и украинского общества в мире. Телевизионная реклама, безусловно, является мощным общественным и культурным механизмом воздействия на массовую аудиторию. Как культурологический феномен она играет важную роль для сохранения национальной культуры и традиций, закрепления и возрождения национального самосознания общества, как в отдельных своих проявлениях, так и в целостном понимании этого вопроса. Это исследование базируется на тщательном системном анализе многочисленных примеров национальной рекламной видеопродукции с точки зрения эффективности ее влияния на отечественную аудиторию.

Ключевые слова: реклама, рекламный видеоролик, аудиовизуальный рекламный произведение, национальная культура, национальные традиции, патриотизм. 


\author{
Svitlana V. Zaria, \\ $\mathrm{PhD}$ in Arts, \\ Head of the Variety singing Department, \\ Kyiv Municipal Academy of Circus and VarieryArts, \\ Kyiv, Ukraine \\ ORCID: 0000-0001-8047-7068
}

\title{
AUDIOVISUAL ADVERTISING WORKS WITH NATIONAL THEMES AS A CULTURAL PHENOMENON OF MODERN UKRAINE
}

\begin{abstract}
The features of modern creative production of such television projects as audiovisual advertising works, characterized by the use of Ukrainian national motives and positioned by advertising campaigns as a cultural phenomenon of modern Ukraine, are explored in the article. The purpose of the study is to trace the current tendency to use the patriotic historical image, national traditions and the past of the Ukrainian people in Ukrainianlanguage advertising as an effective means of mass communication in domestic video production. Also, identify the specifics of the Ukrainian national-cultural component in advertising and highlight the features of the video series of audiovisual advertising works, where the leitmotif of the plot is the Ukrainian national color. Modern Ukrainian trademarks appeal to the theme of national traditions in culture and art, using them in audiovisual works.

Each country has its own advertising style, due to the peculiarities of national consciousness, the history of national traditions. The mentality of the nation and the conditions in which it lives are the main feature of the advertising messages of the country in which they are broadcast. The geographic features of perception and technical capabilities impose their style on any advertising campaign. Promotional videos reflecting folk traditions and associative historical images are a powerful factor in shaping a positive image of both the Ukrainian producer and Ukrainian society
\end{abstract}


in the world. Television advertising is definitely a powerful social and cultural mechanism for influencing a large audience. As a cultural phenomenon, it plays an important role in preserving national culture and traditions, consolidating and reviving the national consciousness of society, both in its individual manifestations and in a holistic understanding of the issue. This intelligence is based on a thorough systematic analysis of numerous examples of national promotional video production in terms of its impact on domestic audiences.

Key words: advertising, advertising video, audiovisual advertising, national culture, national traditions, patriotism.

\section{References}

1. Anashkina N. Rezhysura televizionnoj reklamy [Directing television commercials]. Moscow: Iuniti-dana, 2008. 26 s. (in Russian)

2. Babynina $K$. Kafedra marketinga i reklamy. Reklama i massovaja kultura $\mathrm{k}$ problem opredelenija brenda. [Department of Marketing and Advertising. Advertising and mass culture to the problem of brand definition], Available at: http://kafmr.rggu.ru/index.php?id=622 (in Russian)

3. Bernadskaja J., Marochkin S., Smotrova L. Osnovy reklamy [The basics of advertising]. Moscow: Nauka, 2005. 281 s. (in Russian)

4. Gerasimova $S$. Kulturologiya i teoriya telekommunikacii. [Cultural and telecommunication theory]. Moscow: Gardariki, 2017. 173 s. (in Russian)

5. Elina E. Semiotika reklamy [Semiotics of advertising]. Avaible at: http://book-online.com.ua/read.php?book $=3754$ (in Russian)

6. Mokshancev R. Psihologiya reklamy [Advertising psychology]. Moscow: Infra-M, 2000. 42 s. (in Russian)

7. Narod zhyv, poka zhyvy eho traditcii [The people are alive, while their traditions are alive]. Avaible at: 
http://www.adme.ua/creativity/narod-zhiv-poka-zhivy-ego-tradicii128162/ (in Russian)

8. Ukrainskaja pesnja $\mathrm{v}$ kazhdom iz nas [Ukrainian song in each of us]. Available at: http://www.adme.ua/creativity/ukrainskayapesnya-v-kazhdom-iz-nas-bbdo-kyiv-128492/ (in Russian)

9. Fedorov G. Ukraina ne Rossiya [Ukraine is ot Russia]// Reklamnye idei. 2003. №2. Ss. 36-38 (in Russian)

10. Feofanov $O$. Reklama. Novye tehnologii $\mathrm{v}$ Rossii. [Advertising: new technologies in Russia]. Available at: http://polbu.ru/feofanov_advert/ch03_all.html (in Russian)

11. Hromov L. Reklamnaja dejatelnost [Advertising activity]. Available at: http://udik.com.ua/books/book-815/chapter-29236/ (in Russian) 